http://dx.doi.org/10.7833/115-0-1276

\title{
JESUS' AUTHORITY AND INFLUENCE IN THE GOSPEL OF JOHN: TOWARDS A JOHANNINE MODEL OF LEADERSHIP
}

\author{
Cornelis Bennema \\ Theology and the Development of the South African Society \\ Faculty of Theology, North-West University, South Africa \\ and Union School of Theology, UK
}

\begin{abstract}
This article examines Jesus' authority and influence in the Gospel of John and shows that Jesus' style of leadership is exemplary or prototypical rather than autocratic. Jesus' programme is 'to testify to the truth', that is, to proclaim the divine reality to the world. He uses influence (education and personal example) rather than authority (commands) to urge his disciples to continue his programme, so that people may believe and partake in a life-giving relationship with the Father and Son. This leadership style would be useful for contemporary models of leadership.
\end{abstract}

Key Words: Authority; Gospel of John; Influence; Leadership; Personal Example

\section{Introduction}

While (semi-)popular studies on Christian leadership abound, it is a neglected topic in biblical studies. Andrew Clarke is an exception and has focused on Pauline patterns of church leadership. ${ }^{1}$ In an overview article, he notes that biblical models of leadership often differ from secular models and that principles of biblical leadership are timeless. ${ }^{2} \mathrm{He}$ contends that godly leaders in the Bible are those who continually seek God's will and have the ability to teach it, and who are appropriate examples for others to emulate. ${ }^{3}$ I will show that the Johannine Jesus meets these criteria and functions as an ongoing model for Christian leadership. The specific topic of this study is Jesus' authority and influence in the Gospel of John. According to standard English dictionaries, 'authority' is 'the power or right to give orders, make decisions and enforce obedience', ${ }^{4}$ and 'influence' is 'the capacity to have an effect on the character, development or behaviour of someone or something, or the effect itself'. This study examines John's presentation of Jesus in relation to the following questions. ${ }^{5}$ While Jesus was able to influence various people, his greatest sphere of influence was his disciples. So, how did Jesus influence them and to what end? What is the source of Jesus' authority and how does he use it? What relation has authority and influence in Jesus' programme? What can we learn from Jesus' model of leadership in the Gospel of John for contemporary (Christian) leadership? In answer to these questions, I will argue a threefold thesis. First, the common goal Jesus seeks to promote among his disciples is 'to testify to the truth'. Second, Jesus uses influence rather than authority to

Clarke 1993, 2000b, 2008.

Clarke 2000a:637.

Clarke 2000a:638.

See also Foerster 1964:566-69.

I use 'John' for the author of this gospel without making any claim to his historical identity. 
urge his disciples towards the common goal. Third, the means by which Jesus seeks to influence his disciples is education and personal example. The following three sections correspond to and explain this threefold thesis.

\section{Jesus' Programme}

In this section, I will argue that Jesus' programme was to reveal God to people so that they may share in the divine life ( $\zeta \omega \eta$ ). According to John's dualistic outlook, people naturally belong to the darkness, do not know God and are incapable of doing so because they have no access to the divine world $(1: 5 ; 3: 19 ; 7: 28 ; 8: 47,55 ; 12: 46 ; 17: 25)$. The one who knows God perfectly and is intimate with him is the pre-existent Logos who is sent from the world above to the world below to make God known $(1: 18 ; 3: 31-36 ; 12: 46-50)$. While many people reject him, those who acknowledge him, that is, believe in him, are brought into a life-giving relationship with God (1:10-13; 20:31). In 18:37, Jesus summarises his entire

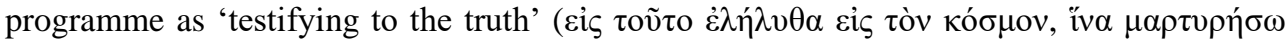
$\tau \tilde{\eta} \dot{\alpha} \lambda \eta \theta \varepsilon i \dot{\alpha})$. In John, 'truth' is shorthand for the reality of God and the world above (cf. $1: 9,17 ; 3: 33 ; 8: 26,40 ; 17: 17)$. In his ministry, Jesus proclaims the divine reality about God and himself in terms of their identity, relationship and mission, and in so doing provides divine life to those who accept his testimony (cf. 3:31-36). Jesus is both the embodiment and dispenser of truth $(1: 14,17 ; 14: 6)$. He communicates God's words, which contain truth that liberates, cleanses and saves $(3: 34 ; 6: 63 ; 8: 31-32 ; 15: 3 ; 17: 17)$. All who belong to the truth belong to Jesus because they have heard his voice and accepted his life-giving words (18:37; cf. 5:25; 10:3-4, 16).

Jesus intends to continue this programme through the disciples, that is, they are also to testify to the divine reality. ${ }^{6}$ Although the phrase 'to testify to the truth' does not occur in relation to the disciples, the concept does. Jesus mentions in 15:26 that 'the Spirit of truth' will testify regarding him - a testimony in which the disciples will partake (15:27). In fact, the Spirit prepares and empowers the disciples' testimony by communicating to them the truth that is in Jesus' teaching $(14: 26 ; 16: 13)$. In the wider context, Jesus exhorts his disciples to counter the false accusations of the world with their Spirit-empowered testimony to the truth. ${ }^{7}$ The purpose of such testimony is to elicit life-giving belief in Jesus (17:20-21; cf. 1:7). Besides this oral testimony, John's gospel itself claims to be a written testimony to the truth $(19: 35 ; 21: 24$; cf. 1 John $1: 1-5)$. The disciples' testimony to the truth, then, is modelled on Jesus' testimony to the divine reality. Having gained a basic understanding of Jesus' programme, I will now turn to the issues of authority and influence in relation to Jesus' programme.

\section{Jesus' Authority and Influence}

\section{Authority}

There are several indications in John's gospel that the source of Jesus' authority is God the Father. First, Jesus is God's authorised agent on earth, sent into the world to make him known $(1: 18 ; 3: 17,32-34 ; 4: 34 ; 5: 24 ; 17: 3-6)$. Second, the Father has given Jesus the Spirit to speak on his behalf $(3: 34){ }^{8}$ In fact, the Father has given Jesus the complete revelation of

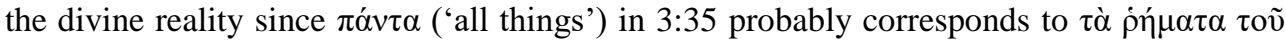
$\theta \varepsilon$ ov ('the words of God') in 3:34. Third, the Father instructs Jesus. On various occasions,

\footnotetext{
6 John (the Baptist) also testified to the truth (5:33; cf. 1:15, 19-29).

7 For a detailed treatment of the disciples' Spirit-empowered testimony, see Bennema 2002:225-47.

8 Most scholars agree that God (rather than Jesus) is the subject of $\delta 1 \delta$ óval ('to give') in 3:34b.
} 
Jesus asserts that he cannot do anything by himself but only speaks and does what he hears and sees from the Father $(5: 19-20 ; 8: 26,28,38 ; 12: 49-50 ; 14: 24 ; 15: 15 ; 17: 7-8){ }^{9}$ Fourth, the Father has authorised Jesus to give life and to judge $(5: 21-27)$ - the unique divine functions. ${ }^{10}$ Fifth, the Father gives or draws people to Jesus $(6: 37,44,65 ; 10: 29 ; 17: 2,6$, 24). Sixth, Jesus' intimate unity with the Father is an authoritative position from which he operates and to which he often appeals $(1: 18 ; 10: 15,30 ; 17: 21-26)$. In sum, Jesus is sent by the Father to do the Father's work under the Father's directive (by means of the Spirit). Jesus' authority is thus rooted in the Father and his personal experience of him. ${ }^{11}$

We find several expressions of Jesus' authority in John's gospel. Jesus asserts, for example, that he has $\dot{\varepsilon} \xi o v \sigma i ́ \alpha$ ('authority') to lay down his life and pick it up at will (10:18), and, rooted in $5: 26$, the $\dot{\varepsilon} \xi o v \sigma i ́ \alpha$ to give (divine) life to people (17:2). Although the term $\grave{\varepsilon} \xi o v \sigma i \alpha$ in relation to Jesus only occurs in $5: 27 ; 10: 18 ; 17: 2$, the idea of authority is also conveyed, for example, by the term $\delta$ i $\delta$ óval ('to give, grant, bestow') in $3: 35 ; 5: 22,26$. In addition, Jesus' 'I am' sayings are his self-disclosures to people and probably an allusion to Exodus 3:14, which describes God's self-revelation to Moses. In fact, the Johannine 'I am' sayings do not merely show Jesus' understanding of himself in relation to God - Jesus is on a par with God himself - but, through the accompanying predicates, reveal how the divine operates among humanity. Jesus' authority also becomes apparent in his being the locus of God's presence and activity, that is, God is at work in the world through Jesus. He is God's special agent of revelation and claims to act on God's behalf (cf. $1: 18 ; 3: 34-35 ; 5: 17)$. On another occasion, Jesus asserts that his words are 'Spirit and life' (6:63). Jesus' command to the dead Lazarus (11:43) demonstrates his authority to give life to whomever he wishes $(5: 21)$. In the footwashing scene, Jesus uses his authoritative status in the group - he is

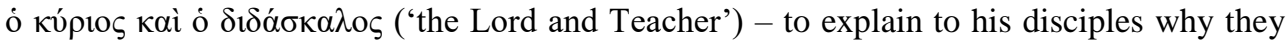
should imitate him (13:13-14, 16; see further the section 'Personal Example'). Jesus' authority was questioned by the Jewish authorities because they found many of his claims and teachings outrageous $(5: 18 ; 6: 41-42,52 ; 8: 13,31-59 ; 10: 33 ; 19: 7)$. Not surprisingly, the Jewish authorities questioned Jesus again about his teaching during his trial (18:19).

\section{Influence}

The term 'influence' in the sense of the capacity to have an effect on someone or something does not correspond to a particular Greek term in John's gospel (nor the rest of the NT). Even as a concept it is difficult to find a Greek equivalent. Besides, I shall not seek to determine how influential Jesus was or which groups of people he was able to influence. Rather, my focus is on Jesus' influence on his (twelve) disciples. Drawing on a Johannine idea (3:8), such as wind, influence is 'invisible' and just as one perceives the direction of the wind through its effects, so one can observe Jesus' effect on his followers through their reactions. The following list of examples (which is not exhaustive) shows Jesus' ability to influence his disciples:

- Jesus was able to influence his earliest disciples. Two disciples of John the Baptist decided to leave their master and remain with their new master Jesus, perhaps because

9 Cf. Witmer 2008:95-105.

10 Bauckham (2008:1-59) makes a compelling case for Jesus' inclusion in the divine identity based on his sharing these divine functions.

11 Similarly, the disciples' source of authority is Jesus: (i) Jesus sends his disciples into the world (just as he was sent by the Father) $(17: 18 ; 20: 21)$; (ii) Jesus empowers them with the Spirit (just as he was empowered by the Spirit) $(14: 26 ; 15: 26 ; 20: 22)$; (iii) Jesus has an intimate unity with the disciples (just as he is one with the Father) $(14: 23 ; 15: 4 ; 17: 20-23)$. 
they learnt that he was the Messiah (1:35-41). Philip accepts the invitation to follow Jesus and learns that Jesus might be the expected prophet-like-Moses (arguably because Jesus taught him) (1:43-45). Jesus' revelatory knowledge of Nathanael's whereabouts causes Nathanael to profess Jesus as the messianic king (1:48-49).

- On the first public occasion of his ministry, at the wedding in Cana, Jesus' performing a miracle has an effect on his disciples in that they believe in him $(2: 11)$, which is the intended Johannine response to Jesus (20:31).

- In 6:60-69, a dramatic sifting among Jesus' disciples is caused by the effect of Jesus' teaching. When a large group of disciples find Jesus' teaching too difficult to take in, they defect. However, Peter affirms, on behalf of the Twelve, that they will remain with Jesus because they have experienced his life-giving teaching.

- During their time with Jesus, some disciples express their willingness to die for their master - Thomas in 11:16 and Peter in 13:37. Although their proposal is premature, their intentions appear sincere and allude to the highest expression of love (15:13). Such a noble gesture is naturally the result of the effect Jesus has had on them.

- The concept of remembrance also shows Jesus' influence on his disciples. While the disciples often fail to understand Jesus during his ministry, they remember (and understand) Jesus' teaching after Easter $(2: 22 ; 12: 16) .{ }^{12}$ This remembered Jesus then becomes the impetus and basis for the disciples' testimony (15:26).

- During the farewell discourses Jesus speaks to his disciples often in enigmatic language, causing confusion and misunderstanding, but when he speaks clearly the effect on his disciples is that it generates knowledge and belief (16:25-30).

- Jesus' influence on John caused him to write down his eyewitness testimony, so that others might also come to know Jesus $(19: 35 ; 20: 31 ; 21: 24){ }^{13}$

\section{Authority and Influence in the Ancient Family}

Jesus' authority and influence must be set within the context of the divine family and ancient families because 'family' is a pertinent theological category in John. ${ }^{14}$ John's gospel presents a divine family, characterised by the relationship between God and Jesus as Father and Son (1:18). This nuclear family is extended to include other 'children', namely those who pledge allegiance to Jesus (1:12-13). But John's concept of the divine family also resembles human families in antiquity. In the ancient Graeco-Roman household (oĩ authority and influence. ${ }^{15}$ Trevor Burke explains that fathers in both Jewish and GraecoRoman families had various duties towards their children, such as procreation, nurture, affection, education and example. ${ }^{16}$ Although the Father is the paterfamilias in John's gospel, he does not have a visible presence and Jesus, as the locus of the Father's presence and his representative, acts in his place $(1: 18 ; 3: 31-32 ; 12: 45$; cf. 5:17). Not surprisingly, then, Jesus brokers or mediates the various family values mentioned above: (i) procreation: belief in Jesus enables people to become 'children of God' (1:12); (ii) nurture: Jesus

12 In light of 14:26, it is most likely that the Spirit reminds them of Jesus' teaching and helps them to understand it (see also the section 'Jesus' Programme').

13 For the case that John's gospel is the eyewitness testimony of the Beloved Disciple, see Bauckham 2006:358-83.

14 For the concept of family in John's gospel, see Van der Watt 2000; Zimmermann 2004:172-183; Coloe 2007.

15 See further Clarke 2000b:79-101.

16 Burke 2003:42-52, 62-89. 
provides true food and drink $(4: 14 ; 6: 35,55)$; (iii) affection: Jesus asserts his love for his disciples $(13: 34 ; 15: 9)$; (iv) education: Jesus teaches his disciples about the divine programme (see further the section 'Education'); (v) example: Jesus sets personal examples regarding appropriate 'family behaviour' (see further the section 'Personal Example').

Friends also occupied influential positions within the ancient Graeco-Roman household or family. In a recent study, Martin Culy elucidates that, in contrast to political and patronclient friendships, private friendships in Graeco-Roman antiquity are characterised by unity, mutuality and equality. ${ }^{17}$ It is not difficult to see that the Johannine Jesus functions as such a friend to his disciples: (i) Jesus often stresses the unity between him and his disciples, and brokers an intimate relationship for them with the Father $(1: 12 ; 15: 4-5$; 17:21-23); (ii) Jesus shares his life with his disciples and, as a friend, teaches them everything about the Father (15:15), so that they might belong to the divine family (cf. 8:35); (iii) towards the end of his life, Jesus creates social equality with his disciples $(13: 4-5 ; 15: 15$;

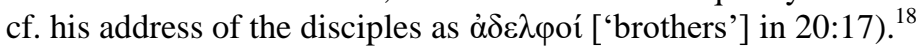

Both Jan van der Watt and Martin Culy acknowledge that there is significant overlap between familial and friendship language in John's gospel, but where Van der Watt views friendship as a subset of family (friends as part of the extended family), ${ }^{19}$ Culy contends that friendship language narrows rather than broadens the circle of intimacy. ${ }^{20}$ As family and friendship language intersect in John's gospel, I agree with Van der Watt that the dominant language is that of family, but with Culy, certain aspects of the divine family are best explained by friendship language.

In sum, Jesus has both authority and influence, but it appears that while he occupies an

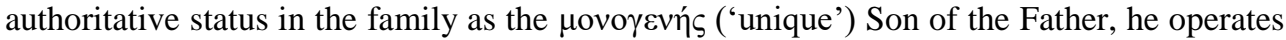
more often as an influential family friend to his disciples. I will test this idea in the following section by examining the way Jesus influences his disciples.

\section{Jesus' Method of Influence}

In this section, I will look at the question of how Jesus influences his disciples to move along with him towards the common goal of testifying about the divine reality. I will develop the answer along two dimensions: (i) education: through Jesus' revelatory teaching, his disciples are 'in the know' and become associates in God's programme; (ii) personal example: Jesus exemplifies what he expects his disciples to do (imitation).

\section{Education}

Jesus communicates his programme about the divine reality (see the section 'Jesus' Programme') primarily through his teaching. Not surprisingly, Jesus is frequently identified as a (God-sent) teacher in John's gospel $(1: 38 ; 3: 2 ; 8: 4 ; 11: 28 ; 13: 13 ; 20: 16$; cf. 6:59; 7:14, $28,35 ; 8: 2,20 ; 18: 20)$. Jesus' educational programme about the divine reality is rooted in God's very own instruction $(7: 16 ; 8: 28$; cf. $12: 49 ; 14: 24)$ and it soon becomes contentious $(5: 18 ; 6: 41-42,52 ; 8: 13,31-59 ; 10: 33 ; 18: 19-20 ; 19: 7)$. Although Jesus' teaching is linked to authority - Nicodemus recognises that Jesus' teaching is authorised by God $(3: 2)$ and

\footnotetext{
Culy 2010:43-61.

Cf. Culy 2010:130-77.

9 Van der Watt 2000:360.

20 Culy 2010:90.
} 
Jesus appeals to his authoritative status in the group as a teacher (13:13-14) - his teaching is also influential. ${ }^{21}$

In the section 'Influence', we observed that Jesus' teaching influences his disciples. While Jesus' teaching is certainly directed at the world $(6: 59 ; 7: 14 ; 8: 2 ; 18: 20)$, he also views it as a family activity as, for example, the lengthy farewell discourses illustrate. ${ }^{22}$ Jesus' education of his disciples is to be ongoing in that, after his departure from this world, the Spirit will take over Jesus' educational function and provide ongoing explanation of Jesus' historical teaching $(14: 26 ; 16: 12-15) .{ }^{23}$ Jesus considers his teaching of such importance that he urges his disciples to keep it and to let his words dwell in them because that will guarantee the indwelling of him and the Father $(14: 23 ; 15: 7)$. Jesus knows that the ongoing effects of his teaching are knowledge of the divine reality and life-giving belief $(17: 8)$.

The idea of Jesus' influence through education also comes to the fore in 15:15b, where Jesus is depicted as Teacher-Friend: 'I have called you friends because (ő $\tau$ ) I have made known to you everything that I have heard from my Father.' It is significant that Jesus presents himself as a friend ( $\varphi$ í $\lambda \circ \varsigma$ ) who educates the disciples through influence rather than authority. Unlike slaves who have no knowledge of the master's business and hence no place within the family (cf. 8:35), the effect of Jesus' revelatory teaching is that the disciples are treated as friends, are informed about God's programme and become his associates.

\section{Personal Example}

Jesus often sets the example for appropriate family behaviour that he expects his disciples to follow. The episode that illustrates this concept of imitation best is the footwashing in John 13 where Jesus gives his disciples an explicit mimetic imperative to wash one another's feet, that is, serve one another in loving humility: 'For I gave you an example

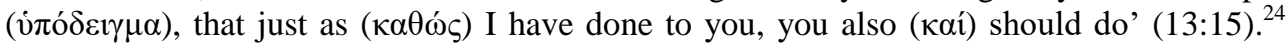

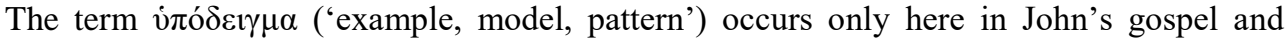
refers back to the footwashing as the visible example or model that Jesus presents for his disciples to imitate. The comparative conjunction $\kappa \alpha \theta \omega \dot{\varsigma}$ in the protasis with the correlative

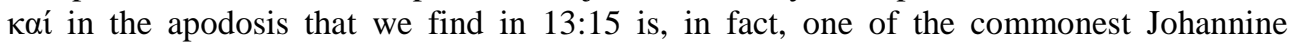
expressions that indicate mimesis (see further below). ${ }^{25}$

In 13:13-14, 16, Jesus provides the rationale for the mimetic imperative in 13:15. These verses contain a threefold argumentum a maiore ad minus for why the disciples cannot be exempt from imitating Jesus: what the person of higher status (Lord, Teacher, Sender) has done, must also be done by the one of lower status (disciples, slaves, messengers). The

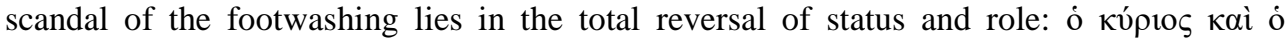

21 For the concept of didactic authority, see Byrskog 1994:ch. 1. The classic study on Jesus as teacher is Riesner 1981.

22 See esp. Van der Watt 2000:266-84.

23 Note also the effect of Jesus' teaching (and the Spirit's ongoing elucidation [1 John 2:27]) on the Johannine believers, resulting in a tremendous claim to knowledge of the divine reality, expressed, for example, by the phrase '(by this) we/you know that' (1 John 2:5, 18, 21; 3:5, 14-16, 19, 24; 4:2, 6, 13; 5:2, 15, 18-20).

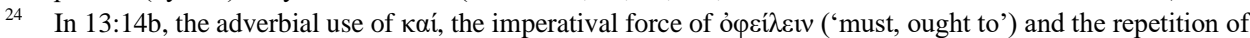
the verb ví $\pi \varepsilon \varepsilon v$ ('to wash') also create a mimetic imperative: '[if I have washed your feet], you must also wash one another's feet.'

25 For a detailed explanation of the nature of mimesis in the footwashing, see Bennema 2014:261-74. 


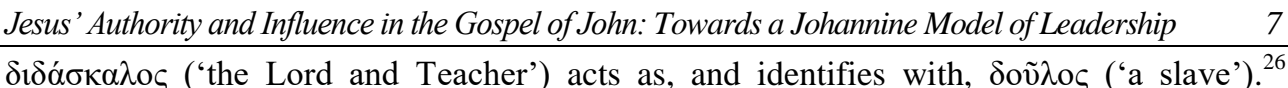

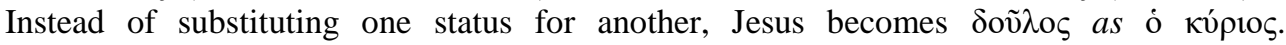
Allegiance to this $\delta$ oṽ ${ }_{0} \varsigma-\kappa v ́ p ı \varsigma$ then demands that oi $\mu \alpha \theta \eta \tau \alpha i$ must be $\delta$ oṽ $\lambda$ oí to one another too. The implication is that the disciples' mimesis involves participation in Jesus' slave-identity. ${ }^{27}$ Jesus' mimetic imperative implies both authority (he can demand this because he has an authoritative status in the group) and influence (he sets the example to follow). In fact, Jesus uses authority in service of influence. Instead of simply commanding his disciples to serve one another, Jesus shows by example the kind of behaviour he expects from his disciples and then seals this with a mimetic imperative. Jesus uses his authoritative status in the group not for the mimetic imperative per se but to provide a rationale or motivational basis for it. As Teacher-Slave, Jesus thus teaches by example.

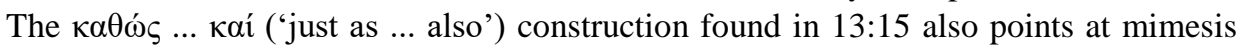
elsewhere in John's gospel. Besides service, Jesus provides other examples that he expects his disciples to follow: 'Just as I have loved you, you also should love one another' (13:34; cf. 15:12); 'Just as you, Father, are in me and I am in you, may they also be in us' (17:21; cf. 17:11, 22); 'Just as the Father has sent me, I also send you' (20:21; cf. 17:18). Occasionally, $\kappa \alpha \theta \omega \varsigma \varsigma$ alone can also indicate mimesis. In 15:10, Jesus clarifies that the

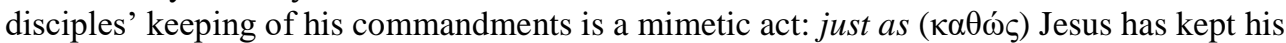
Father's commandments and (hence) abides in his love, so the disciples should imitate

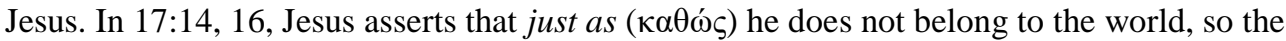
disciples do not belong to the world. Time and again, it is by example that Jesus appeals to the disciples to imitate him. The pattern that emerges is that Jesus shows the example first and his disciples can then (and therefore) imitate him. In this, Jesus uses influence rather than authority, or, more precisely, authority in service of influence, to urge his disciples towards appropriate behaviour within the divine family.

Jesus' method of using his authoritative influence to move his disciples towards the common goal did not arise in a vacuum. I suggest that Jesus learnt this from his Father. The paradigm for the disciples-Jesus mimesis is the Son-Father mimesis in 5:19-20, where Jesus claims he cannot do anything by himself but the Father shows him everything that he is doing so that Jesus can imitate him. John's gospel provides specific instances of the Son-

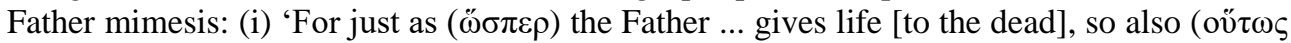

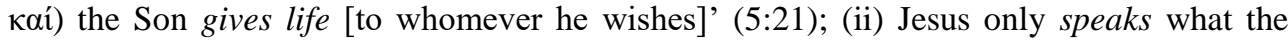
Father has told him $(8: 26,28,38 ; 12: 49-50 ; 15: 15$; cf. 7:16; 14:24; 17:8); (iii) Jesus only acts as the Father instructed him $(14: 31$; $\kappa \alpha \theta \omega \varsigma$... oü $\tau \omega \varsigma$ construction); (iv) just as the Father loves the Son, the Son has also loved the disciples $(15: 9 ; \kappa \alpha \theta \omega ́ \varsigma . . . \kappa \alpha$ í construction); (v) just as the Father honoured the Son, Jesus also honours the disciples (17:22); (vi) just as

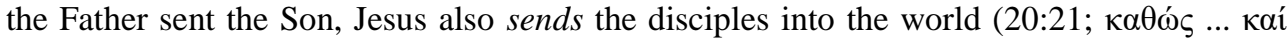
construction). Thus, while 5:19-20 speaks of the Son-Father mimesis in a broad, general sense (Jesus imitates the Father in everything), specific mimetic activities include giving life, speaking, doing, loving, honouring and sending. ${ }^{28}$

It thus seems that Jesus sets a personal example for the disciples to follow because he himself follows the personal example set by the Father. In other words, just as the Father influenced the Son, the Son also influences his disciples. This also implies that Jesus' instruments of influence - education and personal example - are linked. First, as Jesus was

\footnotetext{
26 I contend that $\delta$ oṽ $\lambda$ o in 13:16 should be translated 'slave' rather than 'servant' (contra NRSV, ESV, NIV,

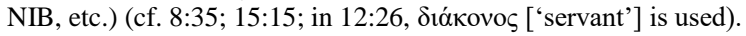

27 Cf. Thomas 1991:115-16.

28 For the concept of mimesis in John's gospel, see Bennema 2016:205-17.
} 
educated by his Father, so he educates the disciples. Second, through his personal example, Jesus teaches his disciples about service, love, indwelling and that they are his agents in this world. Hence, Jesus teaches by personal example. ${ }^{29}$

\section{Conclusion}

Our examination of Jesus' authority and influence in the Gospel of John in relation to his disciples has shown the following. First, the common goal to which Jesus urges his disciples is 'to testify to the truth', that is, to proclaim the divine reality to the world, in order that people might believe and partake in a life-giving relationship with the Father and Son. Second, Jesus primarily uses influence (education and personal example) rather than authority (commands) to urge his disciples towards the common goal. Hence, his leadership is exemplary or prototypical rather than autocratic. Although Jesus does require certain behaviour of his disciples (to serve, love, go, obey, and so on), these commands are based on personal example. Jesus never requires anything of his disciples that he himself has not demonstrated first. Jesus' mimetic imperatives, where he commands his disciples to imitate him, reflect the concept of authority in service of influence. Thus, Jesus' commands to his disciples must be understood in the broader context of his effort to influence his followers. In addition, the Spirit is Jesus' executive power given to the disciples (i) to understand and carry through his educational programme, and (ii) to imitate his personal example.

From our findings I derive two principles: (i) Jesus uses authority in service of influence; (ii) Jesus uses personal example in service of education. This becomes apparent in Jesus' teaching positions as a Teacher-Slave and Teacher-Friend. First, Jesus teaches his

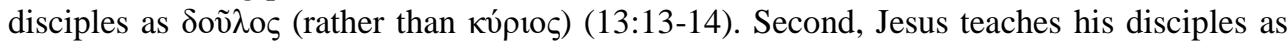

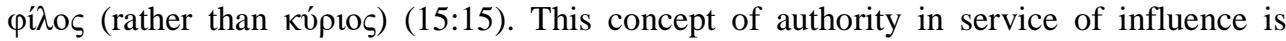
expressed best by Jesus' mimetic imperatives where his personal example is the basis for commanding his disciples to imitate him. While Jesus has an authoritative status in the

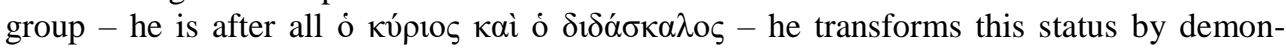
strating servanthood and friendship. Thus, he injects influence into the concept of authority in order to create an influence-imbued authority or an authoritative influence. Jesus 'learnt' this concept of authority in service of influence from the Father, who shows the Son everything so that the Son can imitate him.

John's presentation of Jesus' leadership style has various implications of which I will mention two. First, Jesus' aim is not simply to incorporate his disciples into his programme but also to transform their character. Mimesis or personal example is influential in that it is the primary means of character formation, that is, the goal of mimesis is for the imitator to become like the one who sets the example. ${ }^{30}$ Second, contemporary management studies acknowledge that the most successful leaders today are also those who use influence rather than authority. In addition, modern management theories support the idea of authoritative influence rooted in personal example, and the disciple-Jesus mimesis readily corresponds to contemporary apprenticeship models. Leading or teaching by example in a context of service and friendship would seem the ideal way to groom or mentor upcoming (Christian) leaders.

29 While in the Synoptics Jesus often uses object lessons (parables) to make his point, in John Jesus continually makes himself the object lesson.

30 Others make the same point based on the genre of John's gospel being an ancient Graeco-Roman ßíos (Capes 2003:1-19; Burridge 2007:8-31; Pennington 2012:33-35). 


\section{BIBLIOGRAPHY}

Bauckham, Richard 2006. Jesus and the Eyewitnesses: The Gospels as Eyewitness Testimony. Grand Rapids: Eerdmans.

Bauckham, Richard 2008. Jesus and the God of Israel: God Crucified and Other Studies on the New Testament's Christology of Divine Identity. Grand Rapids: Eerdmans.

Bennema, Cornelis 2002. The Power of Saving Wisdom: An Investigation of Spirit and Wisdom in Relation to the Soteriology of the Fourth Gospel. WUNT II/148. Tübingen: Mohr Siebeck.

Bennema, Cornelis 2014. "Mimesis in John 13: Cloning or Creative Articulation?" Novum Testamentum 56:261-74.

Bennema, Cornelis 2016. "Mimetic Ethics in the Gospel of John." Pages 205-17 in Metapher-Narratio-Mimesis-Doxologie: Begründungsformen frühchristlicher und antiker Ethik. Edited by Ulrich Volp, Friedrich W. Horn and Ruben Zimmermann. WUNT 356. Tübingen: Mohr Siebeck.

Burke, Trevor J 2003. Family Matters: A Socio-Historical Study of Kinship Metaphors in 1 Thessalonians. JSNTS 247. London: T\&T Clark.

Burridge, Richard A 2007. Imitating Jesus: An Inclusive Approach to New Testament Ethics. Grand Rapids: Eerdmans.

Byrskog, Samuel 1994. Jesus the Only Teacher: Didactic Authority and Transmission in Ancient Israel, Ancient Judaism and the Matthean Community. CBNTS 24. Stockholm: Almqvist \& Wiksell.

Capes, David B 2003. "Imitatio Christi and the Gospel Genre.” Bulletin for Biblical Research 13:1-19.

Clarke, Andrew D 1993. Secular and Christian Leadership in Corinth: A Socio-Historical and Exegetical Study of 1 Corinthians 1-6. Leiden: Brill.

Clarke, Andrew D 2000a. "Leadership." Pages 36-40 in New Dictionary of Biblical Theology. Edited by T Desmond Alexander and Brian S Rosner. Downers Grove: InterVarsity Press.

Clarke, Andrew D 2000b. Serve the Community of the Church: Christians as Leaders and Ministers. Grand Rapids: Eerdmans.

Clarke, Andrew D 2008. A Pauline Theology of Church Leadership. LNTS 362. London: T\&T Clark.

Coloe, Mary L 2007. Dwelling in the Household of God: Johannine Ecclesiology and Spirituality. Collegeville: Liturgical Press.

Culy, Martin M 2010. Echoes of Friendship in the Gospel of John. NTM 30. Sheffield: Sheffield Phoenix Press.

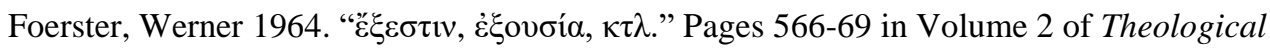
Dictionary of the New Testament. Edited by G Kittel and G Friedrich. Translated by GW Bromiley. 10 vols. Grand Rapids: Eerdmans.

Pennington, Jonathan T 2012. Reading the Gospels Wisely: A Narrative and Theological Introduction. Grand Rapids: Baker Academic.

Riesner, Rainer 1981. Jesus als Lehrer: Eine Untersuhung zum Ursprung der EvangelienÜberlieferung. WUNT II/7. Tübingen: Mohr (Siebeck).

Thomas, John Christopher 1991. Footwashing in John 13 and the Johannine Community. JSNTS 61. Sheffield: JSOT Press. 
Van der Watt, Jan Gabriel 2000. The Family of the King: Dynamics of Metaphor in the Gospel according to John. BIS 47. Leiden: Brill.

Witmer, Stephen E 2008. Divine Instruction in Early Christianity. WUNT II/246. Tübingen: Mohr Siebeck.

Zimmermann, Ruben 2004. Christologie der Bilder im Johannesevangelium: Die

Christopoetik des vierten Evangeliums unter besonderer Berücksichtigung von Joh 10. WUNT 171. Tübingen: Mohr Siebeck. 